\title{
Business practices influencing ethical conduct of small and medium-sized enterprises in Uganda
}

\section{Authors: \\ Dr Jamiah Mayanja ${ }^{1}$ Prof. Sandra Perks ${ }^{2}$ \\ Affiliation: \\ ${ }^{1}$ Makarere University, Kampala, Uganda \\ ${ }^{2}$ Nelson Mandela University, South Africa}

\section{Correspondence to:}

Prof. Sandra Perks,

Department of Business

Management,

Nelson Mandela

University,

PO Box 77000,

Port Elizabeth 6031,

South Africa

E-mail:

sandra.perks@mandela.

ac.za

DOI:

10.15249/11-1-130

\section{Keywords:}

business ethics; knowledge acquisition; management practices; SMEs

\section{Abstract}

Although the significant economic contributions of small and medium-sized enterprises (SMEs) are globally acknowledged, many Ugandan SMEs have not fully integrated ethics into their business strategies. We explored the business practices that influence ethical conduct in SMEs in Uganda. A newly developed self-administered questionnaire was used to collect data from a non-probability convenience sample of 384 SME owners or managers. Management practices of Ugandan SMEs and their employees' knowledge significantly influence their ethical business conduct. SME owners and managers should brief their employees on acceptable ethical business behaviour and develop management practices to reflect their intended ethical business reputation.

\section{Introduction}

Uganda is a landlocked country located in the Eastern part of the African Continent (Nakabugo, Byamugisha \& Bithaghalire, 2008) and has a young and fast-growing population, with the highest youth unemployment rate in Sub-Saharan Africa (International Labour Organisation, 2016). Fifty three percent of Uganda's labour force is self-employed (Uganda Bureau of Statistics, 2016). The transition from an agricultural economy to an industrial economy resulted in robust economic growth in the past decade, especially in the financial services, construction, manufacturing, transportation, telecommunications, energy, infrastructure, and oil and gas sectors (United States Department of State, 2013). Despite Uganda's incredible performance in ensuring political stability and a stable economic environment, Uganda is still ranked as 
having the highest investment and business operational costs within the East African Community region (Doing Business, 2017). It was further noted that the many and costly procedures and time taken to register and start a business discourage business registration.

In Uganda, business start-ups and general business operations are affected by: the lack of access to reliable and affordable electricity supply, costly and time-consuming procedures for obtaining construction permits, high cost of access to credit, costly procedures for resolving commercial disputes in courts of law, poor road- and rail infrastructure, and administrative burdens related to the tax regulation process and trading across borders (Doing Business, 2017). In spite of the airspace liberation between the five East African Community (EAC) member countries, airfreight charges are still very high, thereby contributing to the high cost of doing business (Karuhanga, 2017). SMEs' access to and the use of appropriate technology are limited in Uganda (Uganda Micro, Small and Medium Enterprise Policy, 2015). Furthermore, there are no compliance programmes to detect and prevent bribery or to guide Ugandan businesses' conduct (United States Department of State, 2016).

Although Uganda is regarded as highly entrepreneurial with $10 \%$ of Ugandans starting a business, about one fifth of these businesses fail (Patton, 2016). In Africa, where the private sector is generally not well-developed, SMEs play a critical role in alleviating poverty (Abor \& Quartey, 2010) and comprise of about 90\% of African businesses which contribute to over $50 \%$ to Africa's employment and GDP (Chodokufa, 2009). SMEs are mainly oriented towards solving daily problems, managed on gut feeling with few or no formal management systems, with informal employee relations and communication dominating their operations (Srinivasan, 2009). There is also a weak distinction between their ownership and management roles, with multitasking being quite common. It then follows that their ethical principles are usually implied rather than formally expressed through ethical policies, codes and programmes (Singh, 2009). Unfortunately, SMEs' lack of formal business management practices affects their ability to incorporate responsible and ethical practices in their business operations (Fatoki \& Asah, 2011). Chouaib and Zaddem (2013) observed that SMEs are increasingly exhibiting unethical conduct of deception and opportunism and this may explain the lack of longevity among SMEs.

\section{Problem statement}

The literature on ethical business practices largely focused on large businesses, with limited discussions on SMEs (Banerjee, Dutta \& Mukherjee, 2007). Srinivasan (2009) confirmed that due to the informal nature of SMEs, stringent governance norms that apply to large businesses might not necessarily be applicable to SMEs, thereby providing scope for SME owners to establish their own ethical business practices. Business ethics enacted in larger businesses is different from those of SMEs as only the sole owner or one manager makes business decisions and exerts control over operations; their personal 
attitude and behaviour will guide business behaviour and signal to employees how serious the business is about behaving in an ethical manner (Singh, 2009).

In Uganda today, unethical conduct is an inherent vice within the trading community. Many SME managers display exploitative behaviour such as dishonest, corrupt business practices with tax evasion, inappropriate use of business resources, illicit business participation coupled with opportunism, lack of confidentiality, favouritism and funding embezzlement (Ntayi, Eyaa \& Semukono, 2012). These authors further indicated that SMEs treat employees unfairly, produce substandard goods and mislead customers about product needs and trends. Many SMEs are avoiding product quality assurance certification by the Uganda National Bureau of Standards as the procedure is too stringent (Ministry of Finance, Planning and Economic Development, 2011). There is also evidence of unethical public procurement conduct and behaviour in Uganda with many SMEs failing to adhere to contractual obligations (Ntayi, et al., 2012). Such unethical practices will affect the reputation of their businesses, as well as their ability to attract new customers and retain existing customers.

This research was undertaken in recognition of the importance of having sound business practices in place that promote ethical business conduct in SMEs. Although it is acknowledged that many factors other than business practices can influence ethical business behaviour, this article will focus only on business practices as a key determinant in influencing ethical workplace behaviour. According to Kushnir, Mirmulstein and Ramalho (2010), the most common definitional basis to classify business size is in terms of the number of employees. In this article, small and medium-sized enterprises are considered those businesses that employ more than five but less than 200 employees (Uganda Investment Authority, 2011). Ethical business conduct relates to a business demonstrating high ethical standards in all business practices to maintain its ethical reputation (McMurrian \& Matulich, 2011).

\section{Research objectives}

The primary objective of this study is to determine the business practices that influence the ethical business conduct in Ugandan SMEs. The following secondary objectives address the primary objective:

- To provide a literature review of five selected business practices namely workplace culture, employee knowledge acquisition, management practices, organisational resource management and sound reporting mechanisms, as well as what is regarded as acceptable ethical business behaviour;

- To empirically determine which of the selected business practices influence the ethical business conduct of SMEs in Uganda; and

- To provide recommendations regarding the managerial implications for implementing specific ethical business practices to improve the ethical business conduct of SMEs in Uganda and other developing countries. 


\section{Review of literature}

As all businesses globally face issues such as the increasing awareness of customers' rights and the emphasis on business operation transparency and accountability, there is increased pressure on SMEs to adopt ethical business practices. The important business dimensions that have an effect on SMEs' business ethics practices are related to the special characteristics of SMEs (Lahdesmak, 2005). Khademfar and Amiri (2013) confirmed that besides SMEs being owner-managed, other typical features such as their lack of a formal management structure, not having formal systems and procedures, lack of a workplace culture, limited resource availability and absence of staff training, influence their ethical business conduct.

\subsection{Business practices}

This study has explored the following selected business practices that may influence the ethical business conduct of SMEs: workplace culture, employee knowledge acquisition, management practices, organisational resource management and sound reporting mechanisms.

\subsubsection{Workplace culture}

Workplace culture consists of codes, statements, policies and regulations that affect employees' ethical behaviour (Mehalu, 2011). It encompasses everything from how employees dress, the way they relate to customers, and their interactions with management (Ethics Resource Center, 2013). Workplace culture influences the personalisation of the workplace, as well as the shared views on environmental ethics and behaviours (Cole, Oliver \& Blaviesciunaite, 2014). Ethical dilemmas may occur in situations where there are no clear guidelines on how to act or respond to certain situations (Cant, Wiid \& Kallier, 2013). For example, employees are much more likely to act unethically where a code of ethics does not exist, or top managers disregard it (Miller \& Cross, 2012). The importance of providing employees with clear expectations regarding ethical behaviour in the workplace should not be underestimated (Huhtala, Feldt, Hyvönen \& Mauno, 2013). If businesses provide a clear set of ethical codes and policies, it may positively influence the moral thinking of their employees and result in effective enforcing of these policies (Hellriegel, et al., 2012). SMEs react to ethical dilemmas based on professional business codes rather than on formal business ethics codes (Bajmócy \& Lengyel, 2009). Behavioural policies and procedures communicated in a business lead to a shared perception or belief of what is fair or just (McCain, Tsai \& Bellino, 2010). However, it is important to acknowledge that even good employees can make unethical choices if their workplace culture does not emphasise ethical values. Research conducted by Carroll and Buchholtz (2014) found that when ethical business codes are implemented forcefully and are strongly embedded in the workplace culture, unethical employee behaviours tend to decrease. 


\subsubsection{Employee knowledge acquisition}

Business knowledge can be acquired through training, mentoring, cooperation with partners, suppliers and advisors, or by "stealing" information from other people (Bencsik, 2011). Ethical knowledge can be acquired by employees familiarising themselves with the ethical business codes to know what is regarded as right and wrong in their everyday business conduct (Lee \& Cheng, 2012). It must be noted that knowledge acquisition is a critical element in the effective prevention, investigation, prosecution, and reduction of wrongdoing (Kleinig, 2009). To increase ethical awareness, knowledge acquisition is essential (Shakeel, Khan \& Khan, 2011). The starting point of knowledge acquisition is to train employees to understand and comprehend the business values and moral practices to make sound decisions (Stefanescu \& Doval, 2010). Treviňo and Nelson (2011) suggest that ethical training should already be included in the employee's orientation process. Follow-up training on ethical business behaviour is useful to remind employees about how to behave ethically at all times (Tan, Flack, Bear \& Allen, 2015). Further suggestions include that businesses should send employees from time to time to attend seminars on ethical business conduct to expose them to a wider discussion of business policies, specific case studies and legal requirements specific to ethics (Lluka, 2010). Knowledge acquisition in SMEs is, however, more informal in nature and tends to be obtained from networks such as local business clubs, as well as relationships with customers and suppliers (Schaefer, Williams \& Blundel, 2011). As SMEs are not always aware of all the implications of ethical regulations, their ethical business training is not always effective (Cambra-Fierro, Hart \& Polo-Redondo, 2008). However, any training is beneficial as employees with knowledge can modify their behaviours to reflect the new knowledge (Finn \& Torgeir, 2008) and share it with other employees (Ma'an \& Kalaldeh, 2010).

\subsubsection{Management practices}

Management practices relate to systems and processes designed to support decisionmaking to guide workplace behaviour (Bloom, Genakos, Sadun \& Van Reenen, 2012). It plays an essential role in instilling an ethical business culture because employees pay attention to what is measured, rewarded and disciplined (Treviño \& Nelson, 2011). As management systems influence the ethical orientation of employees, it is important to provide guidelines on the rewards of ethical behaviour and punishment of improper behaviour (Alder, Schminke, Noel \& Kuenzi, 2008). For this reason, businesses must treat employees fairly to encourage ethical behaviour (McCain et al., 2010) as employees' perceptions of unfairness in reward systems increase the likelihood of unethical behaviour (Rhode \& Packel, 2009). Businesses should reward employees who resolve a business dilemma while remaining ethical in their business dealings (Younkins, 2011) and punish employees who violate rules in order to show them the consequences of unethical business conduct (Ferrell \& Ferrell, 2009).

Many SMEs focus on short-term goals and not long-term goals for survival and this prompts their managers to engage in myopic, short-term behaviour that harms the business in the long term (Ordóñez, Schweitzer, Galinsky \& Bazerman, 2009). Many 
SMEs focus mainly on having a positive cash flow and healthy bank balance instead of on business liquidity (Nyabwanga, Ojera, Simeyo \& Nyanyuki, 2013). Without good management practices, the reputation of the business can suffer (Cant, et al., 2013) as it provides opportunities for unethical business behaviour (Ogundele, Hassan, Idris \& Aliu, 2013).

\subsubsection{Organisational resource management}

Yves (2005) is of the opinion that not only financial resources are the root of the unethical business behaviour, but that human resources could also pose problems. The cause of bad business behaviour often lies in mismanaged employee bonus systems and compensation structures, as was evident in the Enron Corporation case that led to a financial crisis and the collapse of the business (Rhode \& Packel, 2009). This is an example of how scarce financial resources can undermine the morality of a business (Lahdesmak, 2005). Monetary compensation can thus harm the reputation of the business if a manager does not act ethically and acts in his/her own interest (Kuryn, 2014). The mere size of the SME limits its financial resources and capabilities and increases the chances of unethical business behaviour (Rune, 2011). SMEs do not access formal funding easily (Mbabazi, 2012), and can often not employ or retain specialised skilled employees (Boateng, 2012). This has resulted in some Kenyan SMEs engaging in unethical business schemes to accept contracts at lower prices to beat their competitors' prices (Tarus \& Nganga, 2013). In a very competitive business environment, a business will do anything to increase its profits because playing by the rules does not necessarily lead to the desired business performance (Kuryn, 2014). For this reason, corruption must be addressed timeously, or else it creates an unfavourable business environment conducive to bribery risks (Bishara, 2011).

\subsubsection{Sound reporting mechanisms}

There is a direct link between a good ethics reporting system and the organisation's code of conduct (Garthson, 2007). It is necessary to communicate in writing to employees about ethical business conduct to close the gap between the spoken word and the execution thereof (Belak \& Milfelner, 2011). Ethics and compliance concerns are normally reported through an array of reporting systems such as telling supervisors and colleagues, phoning toll-free helplines, employing a neutral ombudsman, whistle-blowers reporting incidents, as well as conversations in chat rooms, instant messaging and e-mails (Ethics and Compliance Risk Management, 2007). Employee hotlines ensure confidentiality and anonymity when reporting sensitive work-related matters (Ethics Resource Center, 2013). Allowing anonymous reporting of unethical business conduct by fellow employees or about how they are treated is good for the reputation of the businesses (Ashridge Centre for Business and Society, 2005). It will further prevent unscrupulous employees from behaving unethically due to fear of being exposed and punished (Cicek, 2012). If employee complaints are not resolved amicably, an ombudsman as an outsider can facilitate a fair and equitable resolution of the ethical employee concerns that arise within the business (Treviño \& Nelson, 2011). 
An internal suggestion box for lodging complaints can be desirable and guarantee confidentiality, as both customers and employees can use it (Addai-Minkah, 2011). However, an internal reporting mechanism focuses on the business needs rather than on the needs of its employees and does not inspire trust, because it cannot guarantee confidentiality or anonymity (Garthson, 2007). Many businesses also use ethical compliance manuals to communicate their stance on ethical business behaviour (Belak \& Milfelner, 2011). SMEs tend to have informal reporting mechanisms based on faceto-face interaction with stakeholders, rather than having formal written guidelines (Baumann-Pauly, Wickert, Spence \& Scherer, 2013). In India, rather than using a formal mechanism, SMEs resolve employee disputes in an informal manner based on the employee's reputation, how much they trust the employee and the relationship they have with the employee (Allen, Chakrabarti, De, Qian \& Qian, 2012). The effectiveness of this practice is however debatable, as favouritism can influence human judgment.

\subsubsection{Ethical business conduct}

The business environment has changed in recent years and the issue of business ethics has become even more important for businesses (Cant et al., 2013). Managers expect employees to be ethical and employees expect managers to be ethical (Phatshwane, 2013). Globalisation has brought about a greater need to conduct business in an ethical manner and, most importantly, using it to achieve a competitive advantage (Dutta \& Banerjee, 2011). Many benefits stem from behaving ethically in business. McMurrian and Matulich (2011) note that a business that demonstrates high ethical standards in all business practices, maintains an ethical reputation. Their good reputation results in a high level of customer satisfaction and loyalty that translates into a higher profit, since customers are more inclined to buy from an ethical business (Wiid, Cant \& Niekerk, 2013). Being ethical reduces the transaction costs of generating new customers (Zhang, 2009) and enables businesses to attract more skilled employees (Larkin \& Pierce, 2015). These skilled employees put more effort into their work and thereby increase productivity. According to Lockwood (2007), a business environment that is open and honest results in employees who are loyal and committed to the business. This, in turn, leads to a low staff turnover, as employees will be more likely to remain employed in a business that embraces ethical behaviour (Strandberg, 2009). Abor and Quartey (2010) find that SMEs that operate in an ethical manner adhere to business laws and regulations, and pay their taxes. Ethical businesses pay suppliers promptly (Jones, Felps \& Bigley, 2007). Customers are confident of receiving quality products at agreed-upon prices if buying from ethical businesses (Cambra-Fierro et al., 2008). Muffatto and Giacon (2012) note that ethical businesses display good corporate citizenship behaviour in all their operations, as they are transparent, responsible, fair and accountable.

\section{Research hypotheses and operational definitions}

Based on the preceding literature review, the following five hypotheses were formulated to be tested in this study: 
$\mathrm{H}_{1}$ : Workplace culture influences SMEs' ethical business conduct.

$\mathrm{H}_{2}$ : Employees ethical knowledge levels influence SMEs' ethical business conduct.

$\mathrm{H}_{3}$ : Management practices influence SMEs' ethical business conduct.

$\mathrm{H}_{4}$ : Organisational resource management influences SMEs' ethical business conduct.

$\mathrm{H}_{5}$ : Reporting mechanisms influence SMEs ethical business conduct.

Table 1 depicts the operational definitions of the dependent and independent variables of the study.

Table 1: Operationalisation of variables

\begin{tabular}{|c|c|c|}
\hline Business-related factors & Definitions & Sources \\
\hline Workplace culture & $\begin{array}{l}\text { The business's prevailing values, } \\
\text { attitudes, beliefs and behaviours } \\
\text { that tie employees together }\end{array}$ & $\begin{array}{l}\text { Ethics Resource Center (2013:19); } \\
\text { Mehalu (2011:5); } \\
\text { Sinha \& Mishra (2011:143); }\end{array}$ \\
\hline Management practices & $\begin{array}{l}\text { A set of tools or guidelines used to } \\
\text { shape the values in and promote } \\
\text { ethical behaviour throughout the } \\
\text { business }\end{array}$ & Edwards (2009:142) \\
\hline Knowledge acquisition & $\begin{array}{l}\text { How knowledge is acquired, } \\
\text { processed, understood and } \\
\text { recalled }\end{array}$ & Wisegeek (2015:1) \\
\hline Organisational resources & $\begin{array}{l}\text { The capabilities of the business in } \\
\text { terms of human-, financial-, physical } \\
\text { and material-, information- and } \\
\text { intellectual resources }\end{array}$ & BusinessDictionary.com (2016:1) \\
\hline Reporting mechanisms & $\begin{array}{l}\text { Business mechanisms for } \\
\text { disclosure and communication of } \\
\text { ethical business standards }\end{array}$ & Garthson (2007:1) \\
\hline Ethical business conduct & $\begin{array}{l}\text { Businesses complying with } \\
\text { business laws and regulations, } \\
\text { striving to improve the lives of } \\
\text { their local community and taking } \\
\text { responsibility for the impact of their } \\
\text { activities on the environment }\end{array}$ & $\begin{array}{l}\text { Ferrel \& Ferrel (2009); } \\
\text { Michael (2006); } \\
\text { Smart, Barman \& Gunasekera (2010) }\end{array}$ \\
\hline
\end{tabular}

Cohen, Manion and Morrison (2007) indicate that to conduct good research requires the operationalisation of variables. The operational definitions of the dependent and independent variables guided the development of the items tested in the questionnaire.

\section{Research design and methodology}

In this study, the positivistic research paradigm was adopted. The positivistic paradigm is associated with large sample sizes to enable making inferences about the population (Nwokah, Kiabel \& Briggs, 2009). Four hundred and fifty questionnaires were distributed to SME owners/managers in Kampala based on accessibility and availability, as no complete database of registered SMEs exists in Uganda. Kampala is the capital city of Uganda, with the highest proportion of SME businesses (National Small Business Survey of Uganda, 2015). SMEs' owners and/or managers were selected to participate in the 
survey as they run or manage the businesses and are thus considered the most informed of the ethical business practices employed in the businesses.

Initially business associations supplied their SME databases to assist in identifying the sample respondents. However, when attempting to telephone the businesses on the databases to request participation in the study, it was found that many businesses did not exist or their contact details were incorrect. This resulted in utilising non-probability convenience sampling. Three fieldworkers were supplied with a specific list of business names from the business associations' lists within a specific area in Kampala. However, when fieldworkers went to survey the businesses, many SMEs could not be found and they had not provided their forwarding addresses. It was then decided that while being in that specific area, other businesses in that area be surveyed that meet the criteria for inclusion in the sample. The criteria for inclusion in the sample were that the SMEs must be registered and employ a workforce of between five and 200 employees. Respondents were also asked to refer the fieldworkers to other SMEs that meet the sample criteria.

The fieldworkers verified whether the businesses met the sample criteria before providing the owners/managers with a hard copy of the structured questionnaire. They waited for the completion of the questionnaire or arranged for a time to fetch the completed questionnaire. Some businesses did not complete the questionnaire fully or did not complete it at all within the required data-collection timeframe, resulting in a total sample of 384 completed questionnaires with a response rate of $85 \%$.

A survey questionnaire was developed based on literature and comprised of two sections. In the first section, the biographical data of the businesses were canvassed. In the second section, data pertaining to the perceptions of SMEs on business practice issues influencing their ethical business conduct were tested in 25 items (five items per variable) on a fivepoint Likert-type scale ranging from strongly disagree (1) to strongly agree (5). Ethical business conduct was tested in 10 items on the same five-point Likert scale. According to Zikmund, Babin, Carr and Griffin (2012), a Likert scale provides respondents with a wide range of choices and is suitable to measure the attitude towards an issue.

Three academic experts lecturing in the field of ethics scrutinised the questionnaire for initial face and content validity. This resulted in minor word changes for a few items. Thereafter, based on the first 50 questionnaires received back, it was validated for initial construct reliability by calculating Cronbach's alpha coefficients for the six variables. The Cronbach's alpha coefficients of the five independent variables and ethical business conduct (dependent variable) for the initial pilot sample of 50 questionnaires varied between 0.6 and 0.7 and was regarded as an acceptable reliability level for the research instrument to proceed with surveying the entire sample. These 50 questionnaires were included in the data analysis of the final sample of 384 questionnaires. Although a reliability level of 0.85 is desirable, Suhr and Shay (2009:3) indicate that an acceptable reliability level for research instruments can be as low as 0.50 . This process concluded the initial validation of the newly developed questionnaire.

Data were analysed using a statistical computer package, STATISTICA version 10. The sample met the assumptions for Exploratory Factor Analysis (EFA): a sample size 
of more than 200 respondents, the sample being homogeneous, and only correlations between variables of higher than 0.4 were considered, as well as all outliers removed. Data normality was established by conducting the Kolmogorov-Smirnov test. With all the assumptions met, a principal component EFA (varimax rotation) was carried out to extract the constructs, and assess the validity of the constructs in the measuring instrument. Variables with an Eigenvalue of more than 1.0 were retained as advised by Costello and Osborne (2005). Only item factor loadings above 0.4 were regarded as significant as advised by Hair, Black, Babin, Anderson and Tatham (2006). Cronbach's alpha coefficients were calculated for the full sample to verify the consistency of the inter-item reliability of the research instrument with 0.6 being regarded as an acceptable level of reliability for constructs as recommended by Suhr and Shay (2009). Constructs with less than three items were regarded as weak and unstable (Costello \& Osborne, 2005), and were disregarded. Descriptive and inferential statistics were calculated, with statistical significance measured at the $5 \%$ confidence levels.

\subsection{Sample description}

Table 2 depicts the biographical data of the SMEs surveyed.

Table 2: Biographic data of the surveyed SMEs

\begin{tabular}{|c|c|c|c|}
\hline Demographics & Categories & $\mathbf{N}$ & $\%$ \\
\hline \multirow{4}{*}{ Number of years in business } & Less than 3 years & 59 & 15 \\
\hline & $3-5$ years & 99 & 26 \\
\hline & $6-10$ years & 129 & 34 \\
\hline & More than 10 years & 97 & 25 \\
\hline \multirow{5}{*}{ Form of enterprise } & Sole trader & 110 & 29 \\
\hline & Partnership & 77 & 20 \\
\hline & Private company & 182 & 47 \\
\hline & Trust & 13 & 3 \\
\hline & Others & 2 & 1 \\
\hline \multirow{8}{*}{ Industrial sector } & Manufacturing and Processing & 48 & 13 \\
\hline & Business Services & 97 & 25 \\
\hline & Trade (retailing/wholesaling) & 65 & 17 \\
\hline & Hotels and Restaurants & 52 & 14 \\
\hline & Agriculture and Forestry & 20 & 5 \\
\hline & Education & 69 & 18 \\
\hline & Insurance & 9 & 2 \\
\hline & Health and Social Works & 24 & 6 \\
\hline \multirow{4}{*}{ Number of employees in your business } & $5-10$ & 198 & 52 \\
\hline & $11-20$ & 112 & 29 \\
\hline & $21-49$ & 48 & 12 \\
\hline & $50-200$ & 26 & 7 \\
\hline
\end{tabular}


From Table 2, most of the SMEs (34\%) had been in existence between six and 10 years, $26 \%$ had been in existence between three and five years, $25 \%$ had been in existence for more than 10 years, while only $15 \%$ had been in existence for less than three years. The SMEs surveyed were private limited companies (47\%), sole proprietors (29\%), partnerships $(20 \%)$ or trusts $(3 \%)$. Most SMEs were service businesses (25\%), in education (18\%), the trade (17\%), hotel and restaurants (14\%), as well as manufacturing and processing (13\%) sectors. A few SMEs were in the health and social works (6\%), agriculture and forestry (5\%) and insurance $(2 \%)$ business sectors. More than half $(52 \%)$ of the SMEs employ between five and 10 employees, with 29\% employing between 11 and 20 employees and $13 \%$ employing between 21 and 49 employees. Few businesses (7\%) had more than 50 full-time employees (medium-sized businesses).

\subsubsection{Results of the validity and reliability of the measuring instrument}

As a result of the exploratory factor analysis, six variables (five business practices and ethical business conduct) were extracted, but one of the business practices was disregarded from further analysis as only two items loaded onto the variable. Of the retained variables, some items were regrouped, but the variables did not require renaming as the items fit into the variable description. Table 3 provides a summary of the retained valid items and variables, and an indication of the inter-item consistency scores (Cronbach's alpha) of each variable.

Table 3: Summary of the validity and reliability analysis

\begin{tabular}{l|c|c|c|c}
\hline \multicolumn{1}{|c|}{ Variables } & $\begin{array}{c}\text { Number } \\
\text { of items } \\
\text { retained }\end{array}$ & $\begin{array}{c}\text { Minimum } \\
\text { factor } \\
\text { loadings }\end{array}$ & $\begin{array}{c}\text { Maximum } \\
\text { factor } \\
\text { loadings }\end{array}$ & $\begin{array}{c}\text { Cronbach's } \\
\text { alphas }\end{array}$ \\
\hline Workplace culture (WC) & 4 & 0.496 & 0.585 & 0.503 \\
\hline Employee knowledge acquisition (EKA) & 7 & 0.410 & 0.670 & 0.727 \\
\hline Organisational resource management (ORM) & 5 & 0.419 & 0.729 & 0.607 \\
\hline Management practices (MAP) & 5 & 0.413 & 0.709 & 0.706 \\
\hline Ethical business conduct (EBC) & 6 & 0.576 & 0.723 & 0.749 \\
\hline
\end{tabular}

As can be seen from Table 3, the factor loadings for the five retained constructs vary between 0.410 and 0.729 . Item retention varies between four to seven items per variable. With the exception of workplace culture (WC), all the variables returned Cronbach's alpha coefficient scores of above 0.6 the cut-off point, as advised by Suhr and Shay (2009) to be an acceptable coefficient value. Workplace culture was disregarded from further analysis as there was not sufficient evidence of the reliability of the scales. All the other variables provided sufficient evidence of the reliability of the scales as the Cronbach's alpha coefficients exceeded the cut-off point of 0.60 considered in this study.

\subsubsection{Results of the descriptive statistics}

Employee knowledge acquisition, management practices and ethical business conduct had means that tended towards the agreement of the scale (rating 4). The results of the means imply that SME owners/managers in Uganda agree that employees in SMEs 
in Uganda should be provided with knowledge of ethical business conduct and that there should be management practices in place to encourage ethical business conduct. Respondents further agree (rating 4) that their SMEs are known for their ethical business conduct. Respondents were on average neutral (rating 3) regarding having the ability to manage their organisational resources. All the standard deviations were relatively low (varying from 0.565 to 0.808 ) which indicates low response variances.

\subsubsection{Results of the correlation analysis}

Table 4 depicts the Pearson moment correlation matrix for the dependent variable, ethical business conduct and the independent variables.

Table 4: Pearson product moment correlation matrix of the factors

\begin{tabular}{l|c|c|c|c}
\hline \multicolumn{1}{c|}{ Factors } & EBC & EKA & ORM & MAP \\
\hline Ethical business conduct (EBC) & 1.000 & & & \\
\hline Employee knowledge acquisition (EKA) & 0.437 & 1.000 & & \\
\hline Organisational resource management (ORM) & 0.106 & 0.233 & 1.000 & \\
\hline Management practices (MAP) & 0.384 & 0.568 & 0.284 & 1.000 \\
\hline$p<0.05$
\end{tabular}

Table 4 shows that the independent variables employee knowledge acquisition $(r=0.437)$ and management practices $(r=0.384)$ have significant positive moderate correlations with ethical business conduct. Organisational resource management has weak positive correlations with ethical business conduct $(r=0.106)$ and management practices $(0.284)$. It seems that respondents in this study do not consider organisational resource management to be much associated with ethical business conduct and management practices. Employee knowledge acquisition has a strong association with management practices $(r=0.568)$. Knowledge acquisition could be regarded as a management practice.

\subsubsection{Results of the multiple regression analysis}

It is necessary to establish whether the data are free from multi-collinearity prior to multiple regression analysis testing. Multi-collinearity diagnostics analysis facilitates the identification of measuring items or variables that have a high correlation among themselves (Kraha, Turner, Nimon, Zientek \& Henson, 2012). Nimon, Henson and Gates (2010) regard proper multi-collinearity diagnostics important since extremely correlated predictor variables usually measure the same theoretical concepts, thereby complicating results. It was further advised that a tolerance value of less than 0.1 indicates a serious collinearity problem during multi-collinearity diagnostics analysis. In addition, when the Variance Inflated Factor (VIF) values are greater than 10, there is cause for concern. The tolerance values for the three retained variables ranged from 0.808 to 0.988 with VIF values between 1.011 to 1.236 , demonstrating that there are not high correlations between the business variables, and therefore the data set is free from multi-collinearity problems, enabling multiple regression analysis. 
Table 5 shows the results of the regression analysis and testing of significant relationships between the three valid and reliable independent variables (business practice variables) and the dependent variable (ethical business conduct).

Table 5: Multiple regression analysis results

\begin{tabular}{l|c|c|c|c|c}
\hline \multicolumn{7}{c}{ Dependent variable: Ethical business conduct R2 $\mathbf{0 . 2 1 8}$} \\
\hline Independent variables & Beta & T-value & Sig. $(p)$ & Hypotheses & $\begin{array}{c}\text { Hypotheses } \\
\text { outcome }\end{array}$ \\
\hline Knowledge acquisition & 0.054 & 5.899 & $0.000^{*}$ & $\mathrm{H}_{2}$ & Accepted \\
\hline Organisational resources & 0.033 & -0.617 & 0.537 & $\mathrm{H}_{4}$ & Rejected \\
\hline Management practices & 0.039 & 3.684 & $0.000^{*}$ & $\mathrm{H}_{3}$ & Accepted \\
\hline${ }^{*} \mathrm{p}<0.001$ & & & &
\end{tabular}

The results of the multiple regression analyses show that the independent variables (employee knowledge acquisition, management practices and organisational resource management) explain $21.8 \%$ of the variance in the ethical business conduct of SMEs. Based on the results in Table 5, there are statistically significant relationships $(p<0.001)$ between the independent variables (employee knowledge acquisition and management practices) and the dependent variable, the ethical business conduct of SMEs. The findings signify that SMEs regard knowledgeable employees as important for ethical business behaviour. This finding thus specifically implies that providing employees with periodic ethical business training on moral business practices to educate them on what ethical business behaviour such as corporate values and shared beliefs entail, will guide them to develop an intuition in making sound business decisions and will serve as a platform to encourage knowledge sharing on ethical business practices. The finding is thus consistent with Finn and Torgeir's (2008) observation that employers that acquire knowledge modify their employees' behaviour to reflect the new knowledge, while lack of this knowledge may prevent employees from knowing the requirements for behaving ethically in the business. The findings also imply that SMEs regard having sound management practices in place as important for ethical business behaviour. Treviño and Nelson's (2011) assert that management practices play an essential role in creating an ethical workplace culture because employees pay attention to what is measured, rewarded and disciplined. It is notable that employee knowledge acquisition ( $B=0.054$ at $p<0.001)$ seems more influential in SME ethical business conduct than management practices $(B=0.039$ at $p<0.001)$.

No evidence of a statistically significant relationship was found between organisational resource management and ethical business conduct. The results suggest that SMEs in Uganda do not believe that sound human- and financial-resource management would have a meaningful influence on their ethical business conduct.

\section{Conclusions and recommendations}

In spite of the perception that SMEs experience resource management problems that lead to unethical business conduct, this study found no evidence to that effect. The importance of business practice factors (employee knowledge acquisition and management practices) 
and SME ethical business behaviour in Uganda has been confirmed. It has also been indicated that employee knowledge acquisition can be associated with management practices. For this reason, SMEs in Uganda, or probably in any developing country, should provide employees with ethical business training on moral business practices to educate them on what is regarded as acceptable ethical business behaviour. The first ethical business training session should take place when employment commences as part of the employee orientation programme. The training programme should brief employees on the corporate values of the SME and their expectations regarding shared ethical beliefs. This briefing can provide guidance when employees are confronted with difficult ethical dilemmas to make sound business decisions. Lee and Cheng (2012) confirmed that corporate values help employees make better ethical decisions.

The employee briefing can also serve as a platform to encourage knowledge sharing among employees on solving ethical dilemmas in business dealings and what is regarded as moral business behaviour. Employees must be encouraged to ask one another for professional advice related to ethical business conduct, if uncertain. Tyler and Gnyawali (2009) noted the need to have a strong emphasis on shared beliefs in the business to ensure that all employees focus on the same goals. Ma'an and Kalaldeh (2010) confirmed that knowledge sharing facilitates problem-solving, whether it is an ethical problem or not. Ethics business training should not be a once-off occurrence. Employees need to be reminded of the ethical business values from time to time. It is proposed that SMEs provide employees with ethics business training on an annual basis. SME managers or owners can organise this follow-up training during the revision of their strategic planning session and at the same time establish where employees experience problems in their commitment to ethical business behaviour, and revise their ethical code of conduct if necessary. Treviño and Nelson (2011) point out that follow-up training helps to determine the degree to which trainees actually apply what they have learned.

In addition to employees being knowledgeable, SMEs should show their commitment to ethics in business dealings by having sound management practices in place. From the empirical results, it was clear that Ugandan SMEs regard management practices as mainly reporting procedures and mechanisms that address unethical business behaviour. It seems that SMEs in Uganda have clear guidelines for reporting unethical business behaviour but have no disciplinary procedures in place for punishing wrongdoing. It was not clear whether they have simple systems in place to govern ethical business behaviour such as a written code of business ethics displayed in the business. Hence, SME owners or managers in developing countries such as Uganda should, like large businesses, use their business values to guide the development of a written code of ethics. This code can govern acceptable business behaviour, provides guidelines to resolve complaints in a fair and equitable manner, and outlines the disciplinary procedure for punishing wrongdoing. SMEs should consider having an ethics hotline as a reporting mechanism so that employees and the public can lodge complaints about unethical business behaviour anonymously. Garthson (2007) stresses the importance of providing employees with a hotline to report sensitive work-related misconduct anonymously. All complaints received must be attended to immediately by SME managers or owners and, as far as possible, 
be internally resolved. However, if unable to resolve a complaint internally, it should be referred to an ombudsman to ensure it is resolved in a fair and equitable manner. Treviño and Nelson (2011) confirm using an ombudsman as a preferred way to resolve complaints in a fair and equitable manner, if not being able to resolve it internally.

Paying employees in SMEs market-related salaries may discourage the need for unethical business behaviour and assist in driving their long-term goals. Fernando (2009) regards paying employees market-related salaries as one way of reducing the temptation of employees to cheat. However, it seems that SMEs in Uganda do not regard unethical behaviour as influencing their financial health. They may not realise that customers that encounter their unethical business conduct may not support them again and tell potential customers (family and friends), to not buy from the business. Wiid at al. (2013) confirmed that customers are more inclined to buy from a business that is ethical in its dealings. Non-adherence to business laws and regulations such as paying tax seems not to be regarded as unethical business behaviour. They also disregard the fact that unethical behaviour may impede the attraction of future employees with integrity. Strandberg (2009) noted that employees are more inclined to remain employed in an ethical business.

In conclusion, SMEs, like any business, regardless of size, should first ensure their employees are and remain knowledgeable on what is regarded as ethical business conduct. In addition, appropriate management practices need to be in place to ensure that ethical business conduct is employed consistently throughout the business and the actions of employees are continually monitored to prevent wrongdoing from escalating.

\section{Limitations of the study and future research opportunities}

it is acknowledged, like with all research studies, that the respondents (SME owners/ managers) might not have answered the questions in complete honesty and their perceptions might differ from those of ordinary employees or customers. The development of the research instrument may have included variables not just specific to SMEs, but to businesses in general, as little information is available on SME ethical business conduct. Despite the few limitations identified, this article has added to the limited body of knowledge by identifying two specific business practices (knowledge acquisition by employees and management practices) as influential factors for driving ethical SMEs business conduct within Uganda, a developing country. It is suggested that surveys be conducted amongst ordinary employees and customers to canvass their perceptions of the business practices influencing ethical business behaviour in SMEs. The study results can also be tested in other developing countries to show similarities and contrasts between countries on their views of business practices influencing ethical business conduct. This would provide a less biased view and more honest opinion of which business practices actually influence ethical SME business conduct in Uganda or any other developing country. 
Abor, J. \& Quartey, P. 2010. Issues in SMEs in Ghana and South Africa. International Research Journal of Finance and Economics, 39(6):218-228.

Addai-Minkah, M. 2011. The importance of customer service in the banking industry: The case of Ecobank Ghana Limited. Doctoral dissertation. KNUSTSpace, Institute of Distance Learning, Kwame Nkrumah University of Science and Technology, Kumasi, Ghana.

Alder, G.S., Schminke, M., Noel, T.W. \& Kuenzi, M. 2008. Employee reactions to internet monitoring: The moderating role of ethical orientation. Journal of Business Ethics, 80(3):481-498. https://doi.org/10.1007/ s10551-007-9432-2

Allen, F., Chakrabarti, R., De, S., Qian, J. \& Qian, M. 2012. Financing firms in India. Journal of Financial Intermediation, 21(3):409-445. https://doi.org/10.1016/j.jfi.2012.01.003

Ashridge Centre for Business and Society. 2005. https://www.ashridge.org.uk/Media-Library/Ashridge/ PDFs/Publications/CSRActivities.pdf [Accessed 6 January 2016].

Bajmócy, Z. \& Lengyel, I. 2009. Regional competitiveness, innovation and environment. Szeged: JATE Press.

Banerjee, S., Dutta, S. \& Mukherjee, S. 2007. Ethical practices in small business: A cross-country comparison. Vidyasagar. University Journal of Commerce, 12:1-63.

Baumann-Pauly, D., Wickert, C., Spence, L.J. \& Scherer, A.G. 2013. Organizing corporate social responsibility in small and large firms: Size matters. Journal of Business Ethics, 115(4):693-705. https://doi.org/10.1007/ s10551-013-1827-7

Belak, J. \& Milfelner, B. 2011. Informal and formal institutional measures of business ethics implementation at different stages of enterprise life cycle. Acta Polytechnica Hungarica, 8(1):105-122.

Bencsik, A. 2011. Ethical labyrinth in the period of knowledge acquisition and sharing of knowledge management systems. Problems and Perspectives in Management, 9(3):93-99.

Bishara, N.D. 2011. Governance and completion constraints in the Middle East overcoming the business ethics glass ceiling. Business Law Journal, 48(2):227-283. https://doi.org/10.1111/j.1744-1714.2011.01115.x

Bloom, N., Genakos, C., Sadun, R. \& Van Reenen, J. 2012. Management practices across firms and countries. The Academy of Management Perspectives, 26(1):12-33. https://doi.org/10.5465/amp.2011.0077

Boateng, D. 2012. The role of Small and Medium Enterprises in the economic development of Ghana. http:// www.academia.edu/15253690/ROLE_OF_SMALL_AND_MEDIUM_SCALE_ENTERPRISES_IN_THE_ ECONOMIC_DEVELOPMENT_OF_GHANA [Accessed 6 January 2016].

BusinessDictionary.com. 2016. http://www.businessdictionary.com/definition/organizational-capability.html [Accessed 6 January 2017].

Cambra-Fierro, J., Hart, S. \& Polo-Redondo, Y. 2008. Environmental respect, ethics or simply business: A study in the small and medium enterprise SME context. Journal of Business Ethics, 82(3):645-656. https://doi. org/10.1007/s 10551-007-9583-1

Cant, C.M., Wiid, J.A. \& Kallier, M.S. 2013. Small business owners' perceptions of moral behaviour and employee theft in the small business sector of Nigeria. Gender and Behaviour, 11(2):5775-5787.

Carroll, A. \& Buchholtz, A. 2014. Business and society: Ethics, sustainability, and stakeholder management. 9th edition. Connecticut: Southern Western Cengage Learning.

Chodokufa, K. 2009. An analysis of the business relationship between SMEs and insurance businesses in the Nelson Mandela Metropolitan area. Masters dissertation, University of Fort Hare, South Africa.

Chouaib, A. \& Zaddem, F. 2013. The Ethical Climate at Work. Revue Interdisciplinaire Management, Homme and Enterprise, 5:15-30.

Cicek, V. 2012. Towards global business ethics: A Comparative review on converging business ethics theories and practices. Paper presented at the seventh Silk Road International Conference, 24-26 May, Batumi, Georgia.

Cohen, L., Manion, L. \& Morrison, K. 2007. Research methods in education. 6th edition. New York: Routledge. 
Cole, J.R. Oliver, A. \& Blaviesciunaite, A. 2014. The changing nature of workplace culture. Facilities, 32(13/14): 786-800. https://doi.org/10.1108/F-02-2013-0018

Costello, A.B. \& Osborne, J.W. 2005. Exploratory factor analysis: Four recommendations for getting the most from your analysis. Practical Assessment, Research and Evaluation, 10(7):1-9.

Doing Business. 2017. Equal opportunity for all regional profile East African Community. http://www. doingbusiness.org/reports/ /media/WBG/DoingBusiness/Documents/Profiles/Regional/DB2017/EAC.pdf [Accessed 2 October 2017].

Dutta, S. \& Banerjee, S. 2011. Ethical practices towards employees in small enterprises: A quantitative index. International Journal of Business Management and Economic Research, 2(3):205-221.

Edwards, J. 2009. Understanding management. http://www.docfoc.com/understanding-management-firstcanadian-edition-slides-prepared-by-janice-edwards [Accessed 6 January 2016].

Ethics Resource Center. 2013. England, R. (2008). Plato among the plagiarists: The plagiarist as perpetrator and victim. Journal of the National Collegiate Honors Council - Online archive. https://www.ethics.org/ newsite/research/eci-research/nbes/nbes-reports/nbes-2013 [Accessed 6 January 2016].

Ethics and Compliance Risk Management. 2007. The LRN ethics and compliance risk management practices report. http://erc.webair.com/files/u5/LRNRiskManagementSurvey.pdf [Accessed 6 January 2017].

Fatoki, O.O. \& Asah, F. 2011. The impact of firm and entrepreneurial characteristics on access to debt finance by SMEs in King Williams' Town, South Africa. International Journal of Business and Management, 6(8):170-179. https://doi.org/10.5539/ijbm.v6n8p170

Fernando, A.C. 2009. Business Ethics: An Indian Perspective. New Dehli: Pearson Education.

Ferrell, L. \& Ferrell, O.C. 2009. An enterprise-wide strategic stakeholder approach to sales ethics. Journal of Strategic Marketing, 17(3-4):257-270. https://doi.org/10.1080/09652540903064779

Finn, O.B. \& Torgeir, D. 2008. Knowledge management in software engineering: A systematic review of studied concepts, findings and research methods used. Information and Software Technology, 50(11):1055-1068. https://doi.org/10.1016/j.infsof.2008.03.006

Garthson, J. 2007. Ethics reporting for compliance and beyond. http://garthsonleadership.ca/wp-content/ uploads/2012/09/Ethics-Reporting-for-Compliance-and-Beyond.pdf [Accessed 6 January 2016].

Hair, J.F., Black, W.C., Babin, J.B., Anderson, R.E. \& Tatham, R.L. 2006. Multivariate data analysis. 6th edition. Upper Saddle River: Pearson Prentice Hall.

Hellriegel, D., Slocum, J., Jackson, S., Louw, L., Staude, G., Amos, T. \& Klopper, H.B. 2012. Management. 4th South African Edition. Cape Town: Oxford University Press.

Huhtala, M. Feldt, T., Hyvönen, K. \& Mauno, S. 2013. Ethical organizational culture as a context for managers' personal work goals. Journal of Business Ethics, 114(2):265-282. https://doi.org/10.1007/s10551-012-1346-y

International Labour Organisation. 2016. Facing the growing unemployment challenges in Africa. http://www. ilo.org/addisababa/media-centre/pr/WCMS_444474/lang--en/index.htm [Accessed 2 October 2017].

Jones, T.M., Felps, W. \& Bigley, G.A. 2007. Ethical theory and stakeholder-related decisions: The role of stakeholder culture. Academy of Management Review, 32(1):137-155. https://doi.org/10.5465/ AMR.2007.23463924

Karuhanga, J. 2017. Open skies could earn EAC \$200 million annually: Study. http://www.newtimes.co.rw/ section/read/208920/ [(Accessed 3 October 2017].

Khademfar, M. \& Amiri, S.A. 2013. The Relationship between ethical leadership and organizational performance: Small review of Malaysian studies. International Journal of Business and Social Science, 4(1):114-119.

Kleinig, J. 2009. The ethical perils of knowledge acquisition. Criminal Justice Ethics, 28(2):201-222. https://doi. org/10.1080/07311290903181218

Kraha, A., Turner H., Nimon K., Zientek, L.R. \& Henson, R.K. 2012. Tools to support interpreting multiple regression in the face of multicollinearity. Front Psychology, 3:44. https://doi.org/10.3389/fpsyg.2012.00044 
Kuryn, J.L. 2014. Creation of an ethical business: The implementation of virtuous behaviour and shared values and goals. http://rebirthofreason.com/Articles/Kuryn/Creation_of_an_Ethical_Business_The_ Implementation_of_Virtuous_Behavior_and_Shared_Values_and_Goals.shtml [Accessed 6 January 2016].

Kushnir, K., Mirmulstein, M.L. \& Ramalho, R. 2010. Micro, small, and medium enterprises around the world: How many are there, and what affects the count? http://www.ifc.org/wps/wcm/connect/9ae1dd80495860d 6a482b519583b6d16/MSME-Cl-AnalysisNote.pdf?MOD=AJPERES [Accessed 6 January 2016].

Lahdesmak, M. 2005. When ethics matters - interpreting the ethical discourse of small nature-based entrepreneurs. Journal of Business Ethics, 61(1):55-68. https://doi.org/10.1007/s10551-005-5333-4

Larkin, I. \& Pierce, L. 2015. Compensation and employee misconduct: The inseparability of productive and counterproductive behaviour in firms. http://apps.olin.wustl.edu/faculty/pierce/larkinpiercepost.pdf [Accessed 6 January 2016].

Lee, S.T. \& Cheng, I.H. 2012. Ethics management in public relations: Practitioner conceptualizations of ethical leadership, knowledge, training and compliance. Journal of Mass Media Ethics, 27(2):80-96. https://doi.or g/10.1080/08900523.2012.694317

Lluka, V. 2010. Business ethics: Some theoretical issues Munich personal. http://mpra.ub.uni-muenchen.de/26716/ [Accessed 6 January 2016].

Lockwood, N.R. 2007. Leveraging employee engagement for competitive advantage. Society for Human Resource Management Research Quarterly, 1:1-12.

Ma'an, J. \& Kalaldeh, T. 2010. The relationships among organizational knowledge sharing practices, employees' learning commitments, employees' adaptability, and employees' job satisfaction: An empirical investigation of the listed manufacturing companies in Jordan. Interdisciplinary Journal of Information, Knowledge, and Management, 5:327-356.

Mbabazi, A. 2012. The Uganda's top 100 mid-size companies. http://opm.go.ug/assets/media/resources/445/ Top\%20100\%20SMEs\%20Gala\%20Dinner\%20Speech.pdf [Accessed 6 January 2016].

McCain, C.S.L., Tsai, H. \& Bellino, N. 2010. Organizational justice, employees' ethical behaviour, and job satisfaction in the casino industry. International Journal of Contemporary Hospitality Management, 22(7):992-1009. https://doi.org/10.1108/09596111011066644

McMurrian, R.C. \& Matulich, E. 2011. Building customer value and profitability with business ethics. Journal of Business and Economics Research, 4(11):11-18. https://doi.org/10.19030/jber.v4i11.2710

Mehalu, K.G. 2011. Social responsibility and managerial ethics: A focus on MNCs. http://essay. druckerchallenge.org/fileadmin/user_upload/essays_pdf/kidusmehalu.pdf [Accessed 6 January 2016].

Michael, M.L. 2006. Business ethics: The law of rules. Business Ethics Quarterly, 16(4):475-504. https://doi. org/10.5840/beq200616445

Miller, R. \& Cross, F. 2012. The legal environment of business: Text and cases, ethical, regulatory, global, and corporate issues. Ohio: Southern-Western Cengage Learning.

Ministry of Finance, Planning and Economic Development. 2011. http://www.ugandainvest.go.ug/index.php/ casestudies/docdownload/63-msme-policy [Accessed 8 January 2016].

Muffatto, M. \& Giacon, P. 2012. Entrepreneurial Strategies and policies for economic growth. Padova: Libreriauniversitaria.

Nakabugo, M.G., Byamugisha, A. \& Bithaghalire, J. 2008. Future schooling in Uganda. Journal of International Cooperation in Education, 11(1):55-69.

National Small Business Survey of Uganda. 2015. http://fsduganda.or.ug/files/downloads/National\%20 Small\%20Business\%20Survey\%20report.pdf [Accessed 2 October 2017].

Nimon, K., Henson, R. \& Gates, M. 2010. Revisiting interpretation of canonical correlation analysis: A tutorial and demonstration of canonical commonality analysis. Multivariate Behavioral Research, 45(4):702-724. https://doi.org/10.1080/00273171.2010.498293

Ntayi, M., Eyaa, S. \& Semukono, F.J. 2012. Perceived enforcement of informal buyer-supplier contractual arrangements in Ugandan Small and Medium Enterprises SMEs. Global Journal of Management and Business Research, 12(8):42-59. 
Nwokah, N.G., Kiabel, B.D. \& Briggs, A.E. 2009. Philosophical foundations and research relevance: Issues for marketing information research. European Journal of Scientific Research, 33(3):429-437.

Nyabwanga, R.N., Ojera, P., Simeyo, O. \& Nyanyuki, N.F. 2013. An empirical analysis of the liquidity, solvency and financial health of small and medium-sized enterprises in Kisii Municipality, Kenya. European Journal of Business and Management, 5(8):1-15.

Ogundele, O.J.K., Hassan, A.R., Idris, A.A. \& Aliu, A.A. 2013. Ethical problems affecting SMEs in Nigeria, and their impact on E-Business development. International Journal of Economics and Management Science, 2(10):1-15.

Ordóñez, L.D., Schweitzer, M.E., Galinsky, A.D. \& Bazerman, M.H. 2009. Goals gone wild: The systematic side effects of overprescribing goal setting. The Academy of Management Perspectives, 23(1):6-16. https://doi. org/10.5465/AMP.2009.37007999

Patton, A. 2016. Uganda is a land of entrepreneurs, but how many startups survive? https://www.theguardian. com/global-development-professionals-network/2016/feb/16/uganda-is-a-land-of-entrepreneurs-but-howmany-startups-survive [Accessed 3 October 2017].

Phatshwane, P.M. 2013. Ethical Perceptions of Managers: A preliminary study of small and medium enterprises in Botswana. American International Journal of Contemporary Research, 3(2):41-49.

Rhode, D.L. \& Packel, A.K. 2009. Ethics and nonprofits. Stanford Social Innovation Review, 7(3):28-35.

Rune, A. 2011. Corruption and SMEs: Exploring the business case for western SMEs to counter involvement in administrative corruption in developing countries. Masters thesis. Copenhagen Business School, Business and Development Studies, Frederiksberg, Denmark.

Schaefer, A., Williams, S. \& Blundel, R. 2011. SMEs' construction of climate change risks: The role of networks and values. SMEs Moving Towards Sustainable Development, International Conference, 20-22 October, Montreal, Canada.

Shakeel, M., Khan, M.M. \& Khan, M.A. 2011. Impact of culture on business ethics. Far East Journal of Psychology and Business, 3(2):59-70.

Singh, L.A. 2009. Measuring the ethical quotient of corporations: The case of small and medium enterprises in India. Journal of the Oxford Round Table, 5(1):1-27.

Sinha, A.K. \& Mishra S.K. 2011. Factors affecting ethical decision-making in corporate setting. Journal of Management Ethics and Spirituality, 4(1):135-154.

Smart, V., Barman, T. \& Gunasekera, N. 2010. Incorporating ethics into strategy: Developing sustainable business models. http://www.cimaglobal.com/Documents/Professional\%20ethics\%20docs/Incorporatingethicsinto strategyweb1.pdf [Accessed 1 August 2017].

Srinivasan, V. 2009. CSR and ethics in MSMEs in India. Africa Journal of Business, 4(2):32-36.

Stefanescu, C. \& Doval, E. 2010. Implications of ethical values on management. Review of General Management, 11(1):36-41.

Strandberg, C. 2009. The role of human resource management in corporate social responsibility issue brief and roadmap. http://corostrandberg.com/wp-content/uploads/2009/12/csr-hr-management.pdf [Accessed 1 August 2017].

Suhr, D. \& Shay, M. 2009. Guidelines for reliability, confirmatory and exploratory factor analysis. In Conference Proceedings of the Western Users of SAS Software, 1-3 September, San Jose, California.

Tan, K.M., Flack, F.S., Bear, N.L. \& Allen, J.A. 2015. An evaluation of a data linkage training workshop for research ethics committees. Bio Med Central Medical Ethics, 16(1):13-16. https://doi.org/10.1186/s12910015-0007-y

Tarus, D.K. \& Nganga, S.I. 2013. Small and medium-size manufacturing enterprises growth and work ethics in Kenya. Developing Country Studies, 3(2):51-59.

Treviño, L.K. \& Nelson, K.A. 2011. Managing business ethics. 5th edition. New York: John Wiley.

Tyler, B.B. \& Gnyawali, D.R. 2009. Managerial collective cognitions: An examination of similarities and differences of cultural orientations. Journal of Management Studies, 46(1):93-126. https://doi.org/10.1111/ j.1467-6486.2008.00795.x 
Uganda Bureau of Statistics. 2016. Statistical abstract. http://www.ubos.org/onlinefiles/uploads/ubos/ statistical_abstracts/2016\%20Statistical\%20Abstract.pdf [Accessed 3 October 2017].

Uganda Investment Authority. 2011. Baseline Survey of Small and Medium Enterprises in Uganda Draft Final Report. Kampala: Kampala Printers.

Uganda Micro, Small and Medium Enterprise Policy. 2015. https:/www.ugandainvest.go.ug/wp-content/ uploads/2016/02/Final-MSME-Policy-July-2015.pdf [Accessed 3 October 2017].

United States Department of State. 2013. Investment Climate Statement Uganda. Bureau of Economic, Energy and Business Affairs Report. http://www.state.gov/e/eb/rls/othr/ics/2013/204753.htm [Accessed 2 October 2017].

United States Department of State. 2016. Investment Climate Statement for 2016 - Uganda. https://www.ecoi. net/local_link/332439/460499_en.html [Accessed 2 October 2017].

Wiid, J.A., Cant, M.C. \& Niekerk, C. 2013. Moral behaviour and ethical misconduct In Nigerian Small Businesses. International Business and Economics Research Journal, 12(9):1087-1100. https://doi. org/10.19030/iber.v12i9.8054

Wisegeek. 2015. What is knowledge acquisition? http://www.wisegeek.com/what-is-knowledge-acquisition. htm [Accessed 6 January 2016].

Younkins, E.W. 2011. Morality, success, and individual happiness in business: The virtuous pursuit of values and goals. Libertarian Papers, 3:1-26.

Yves, F. 2005. The reasons behind non-ethical behaviour in business and entrepreneurship. Journal of Business Ethics, 60(3):265-279. https://doi.org/10.1007/s10551-005-0134-3

Zhang, Y. 2009. A study of corporate reputation's influence on customer loyalty based on PLS-SEM model. International Business Research, 2(3):28-35. https://doi.org/10.4018/jebr.2006070103

Zikmund, W., Babin, B., Carr, J. \& Griffin, M. 2012. Business research methods. Connecticut: Southern Western Cengage Learning. 